\title{
Effect on Treatment of the Landfill Leachate with the Furrow Irrigation in Onland Planting Reed (Phragmites)
}

\author{
Kun Shi ${ }^{1}$, Ming Zou ${ }^{1}$, Hongxiang Cai $^{2}$ \\ ${ }^{1}$ School of Environmental and Chemical Engineering, Dalian Jiaotong University, Dalian, China \\ ${ }^{2}$ Extensive Center of Agricultural Technology, Dalian, China \\ Email: skshikun@sohu.com
}

Received July 1, 2012; revised August 3, 2012; accepted August 13, 2012

\begin{abstract}
The furrow irrigation tests were done to estimated the efficiency of the HRT (Hydraulic Retention Time) and landfill leachat collected from Dalian Maoyimgzi Municipal Solid Waste Landfill, which contained high level of COD (Chemical Oxygen Demand, $3.8 \times 10^{4} \mathrm{mg} \cdot \mathrm{L}^{-1}$ ), TOC (total carbon, $4.8 \times 10^{3} \mathrm{mg} \cdot \mathrm{L}^{-1}$ ), TN (total nitrogen, $2.9 \times 10^{3} \mathrm{mg} \cdot \mathrm{L}^{-1}$ ) and SS (Suspended Solids, $6.5 \times 10^{2} \mathrm{mg} \cdot \mathrm{L}^{-1}$ ), using the reed (phragmites) cultivated onland located in south area of Dalian Jiaotong University. The results showed that: 1) The TN concentration was decreased from $9.8 \times 10^{2} \mathrm{mg} \cdot \mathrm{L}^{-1}$ in the landfill leachate to $7.6 \times 10^{2} \mathrm{mg} \cdot \mathrm{L}^{-1}$ in the soil water, and the $22.4 \%$ of the removal rate; 2) The TOC concentration was decreased from $4.8 \times 10^{3} \mathrm{mg} \cdot \mathrm{L}^{-1}$ in the landfill leachate to $1.0 \times 10^{3} \mathrm{mg} \cdot \mathrm{L}^{-1}$ in the soil water, and the $79.2 \%$ of removed rate; 3) The water concentration in the soil was no significant difference of irrigation between the water and the landfill leachate; 4) $\triangle \mathrm{HRT}$ was 2.1 hours in irrigation $39 \mathrm{~L}$ of the water and landfill leachate and 1.3 hours in the $9 \mathrm{~L}$.
\end{abstract}

Keywords: Cultivated Onland; Landfill Leachate; Total Nitrogen (TN); Total Carbon (TOC)

\section{Introduction}

There are many project cases and researches on treating the landfill leachate with constructed wetland around the world. For example, Ithaca Landfill in New York in the USA started to treat the landfill leachate with constructed wetland in 1989 [1]. Chunchula Landfill in the city named Mobile in Alabama in the USA mixed the wastewater and landfill leachate together and treated with constructed wetland, and expelled at the standard [2]. Des Moines area in Aihua Florida in the USA treated the landfill leachate with constructed wetland, and the removal rate was significant [3]. Perdido Landfill in Escambia in Finland is running and treating the landfill leachate with constructed wetland for 13 years in cold temperature. Canada, United Kingdom, Australia and Poland and some other countries applied to the constructed wetland system process for landfill leachate [4]. Laogang Land fill in Shanghai in China has a certain scale and effective application on treating the landfill leachate with constructed wetland by the way of "Facultative anaerobic pond + Facultative anaerobic and aerated ponds + Aeration pond + Constructed Wetland" [5], and the average removal rate of COD was $66 \%$ [6]. The city named Monroe in New York in the USA treated the landfill leachate from Northeast-quadrant Solid Waste Facility after sealing of landfill with constructed wetland, and the average removal rate of COD was 68\%. Dragonja Landfill in Slovenia treated the landfill leachate with constructed wetland, and the average removal rate of COD was $68 \%$ [7]. Esval Landfill in Norway treated the landfill leachate by the way of "Oxidation pond + constructed wetland", the HRT was 40d, and the average removal rate of COD was $88 \%[8,9]$. But there is little reach on treating the landfill leachate with the method of land fill leachate preferential flow and reflowing tests on undisturbed soil cuboids in cultivated onland.

Cultivated onland treatment of landfill leachate is a relatively new wastewater treatment technology, and was attention and gradually applied in recent decades [10-16]. Landfill leachate has a large concentration of pollutants, black, dark green and chocolate color, and complex components, so it's hard to treat by tradition ways. As investigation that the main treatment of landfill leachate in China is reverse osmosis, and it has good treatment effect, but there are running unstable, expensive, consume large and some other shortcomings [17-22]. In addition, there is no effective disposal traditional way for the production of concentrated solution, and any mistake will cause secondary pollution. Therefore, research on cultivated onland treatment of landfill leachate is of great 
significance. the applicable criteria that follow.

\section{Materials and Methods}

\subsection{Materials}

The landfill leachate was collected from Dalian Maoyingzi Municipal Solid Waste Landfill, which contained high level TN $\left(9.8 \times 10^{2} \mathrm{mg} \cdot \mathrm{L}^{-1}\right)$ and TOC $\left(4.8 \times 10^{3}\right.$ $\left.\mathrm{mg} \cdot \mathrm{L}^{-1}\right)$. Its color was dark brown and smelled bad. The cultivated onland located in the South Area of Dalian Jiaotong University. The main onland plant was reed (Phragmites) with a spacing of $0.5 \mathrm{~m}$, and the roots extended about $30 \mathrm{~cm}$ depth under the onland surface. Preparing instruments and medicines used for analyzing the TN and TOC by international standard methods, and Marriott Bottles, polyethylene plastic films, collecting basins, tape measure, shovel, pickaxe, scraper knife, adhesive tapes, sieve, bezel and some other equipment and tools.

\subsection{Methods}

The schematic diagram of experiment ground can be seen from Figures. Digging the soil in between the reed of 2 ridges with long $(1 \mathrm{~m})$, wide $(0.34 \mathrm{~m})$ and depth $(0.25 \mathrm{~m})$, and became the furrow, and dripping the landfill leachate (Figure 1) and the deionized water (Figure 2) into the furrow with two times, irrigating the volume

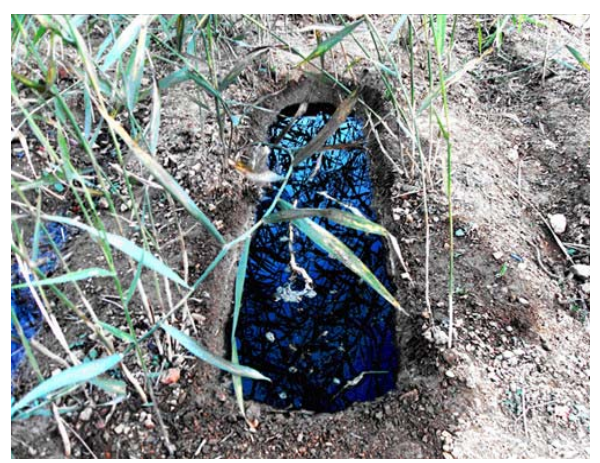

Figure 1. Landfill leachate treatment of furrow irrigation.

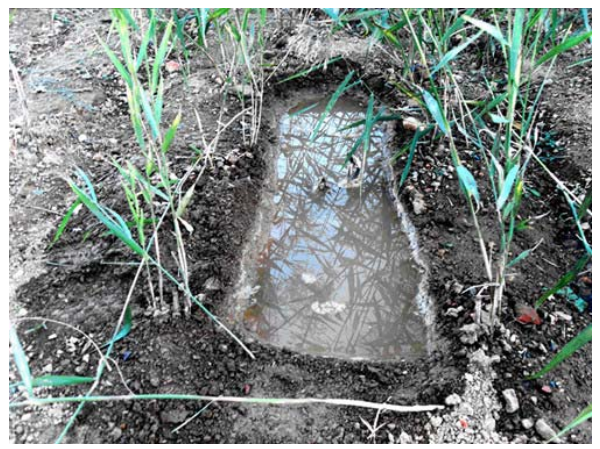

Figure 2. Deionized water treatment of the furrow irrigation. of the water and the landfill leachate was $39 \mathrm{~L}$ and $9 \mathrm{~L}$, respectively. The experiment was 4 times of repeats. While the water and the landfill leachate had permeated the ground, having been taken $1 \mathrm{~kg}$ of the soil nearby 5 $\mathrm{cm}$ of the furrow were 12 samples, and $\mathrm{N}, \mathrm{C}$ and water concentrations in the samples were measured by semimicro-Kjeldahl azotometer, external heating potassium dichromate and drying and weighing method.

\section{Results and Discussion}

\subsection{Total Nitrogen Contents in the Landfill Leachate and the Soil}

Total nitrogen in the $48 \mathrm{~L}$ of the landfill leachate is 47.14 $\mathrm{g}$, and the soil (valume $1.00 \times 0.25 \times 0.34 \mathrm{~m}$, density $2.65 \mathrm{~g} / \mathrm{cm}^{3}$ and background value $0.58 \mathrm{~g} / \mathrm{kg}$ ) is $130.65 \mathrm{~g}$. It is $177.79 \mathrm{~g}$ of both in the landfill leachate and the soil. The total nitrogen content in the soil might be $0.79 \mathrm{~g} / \mathrm{kg}$ as the theory. In 1 day after treatment, the $0.76 \mathrm{~g} / \mathrm{kg}$ its content was measured (Figure 3), The content was very significantly different $(P<0.01)$ from the deionized water $(0.53 \mathrm{~g} / \mathrm{kg})$ and background value $(0.58 \mathrm{~g} / \mathrm{kg})$. The landfill leachate surely increases the nitrogen concentrations in the soil. No significant difference $(P>0.05)$ of the contents was measured between the deionized water and the background value. The TN concentration was decreased from $9.8 \times 10^{2} \mathrm{mg} \cdot \mathrm{L}^{-1}$ in the landfill leachate to $7.6 \times 10^{2} \mathrm{mg} \cdot \mathrm{L}^{-1}$ in the soil water, and the $22.4 \%$ of the removal rate.

\subsection{Total Carbon Contents in the Landfill Leachate and the Soil}

The total carbon of $48 \mathrm{~L}$ of the landfill leachate is 228.77 $\mathrm{g}$, and the soil (valume $1.00 \times 0.25 \times 0.34 \mathrm{~m}$, density $2.65 \mathrm{~g} / \mathrm{cm}^{3}$ and background value $4.67 \mathrm{~g} / \mathrm{kg}$ ) is $1051.92 \mathrm{~g}$. It is $1280.69 \mathrm{~g}$ of both in the landfill leathate and the soil. The total carbon content might be $5.69 \mathrm{~g} / \mathrm{kg}$ as the theory. In 1 day after treatment, the $10.01 \mathrm{~g} / \mathrm{kg}$ of its content was measured (Figure 4). The content was very significantly different $(P<0.01)$ from it in the treatment of the deionized water $(7.81 \mathrm{~g} / \mathrm{kg})$ and background value $(4.67 \mathrm{~g} / \mathrm{kg})$; the contents in the treatment of the deionized water was very significantly different $(P<0.01)$ from the background value. Water and landfill leachate surely increase the total carbon contents. The TOC concentration was decreased from $4.8 \times 10^{3} \mathrm{mg} \cdot \mathrm{L}^{-1}$ in the landfill leachate to $1.0 \times 10^{3} \mathrm{mg} \cdot \mathrm{L}^{-1}$ in the soil water, and the $79.2 \%$ of removed rate.

\subsection{Water Contents and Hydraulic Retention Time}

In the 1 day after the treatments, the average water contents of the background value, the deionized water and 


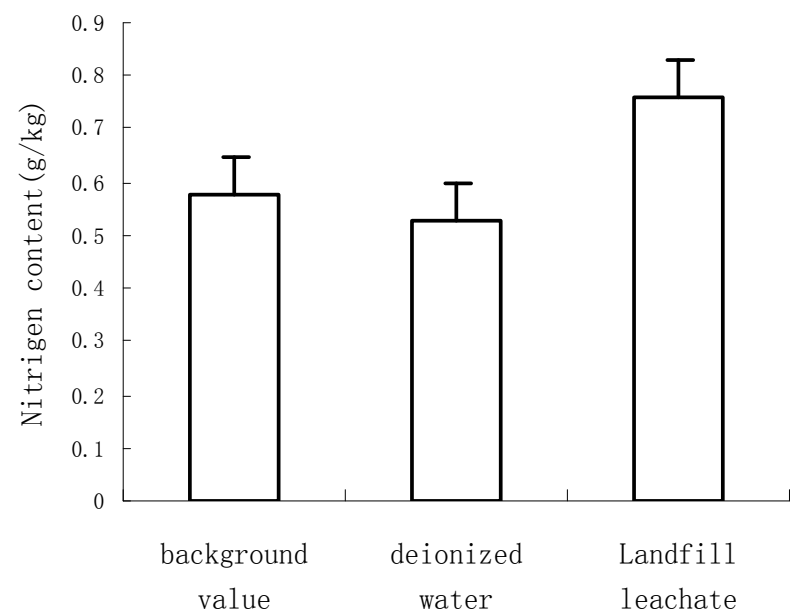

Figure 3. Total nitrogen contents.

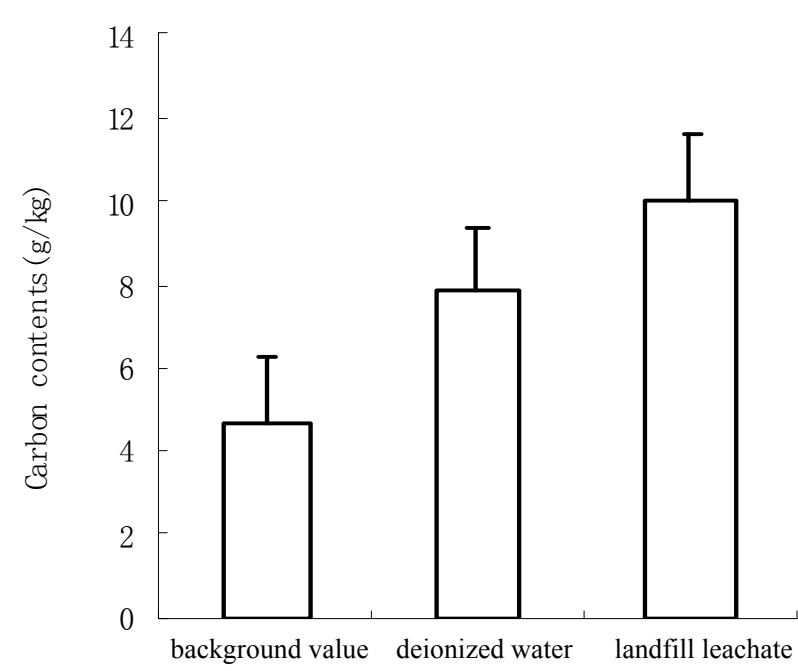

Figure 4. Total carbon contents.

the landfill leathate in the soil were $9.51 \%, 17.23 \%$ and $17.18 \%$, respectively. It ranged from $7.41 \%$ to $10.71 \%$ in the soil of the background value, from $12.50 \%$ to $20.00 \%$ in soil of the deionized water and from $15.79 \%$ to $18.52 \%$ in the soil of the landfill leathate. It was no significant difference $(P>0.05)$ of irrigation between the water and the landfill leachate, and background value. First time, HRT of irrigating $39 \mathrm{~L}$ the deionized water was 15 hours and it of the landfill leathate was 12.9 hours; then it of the $9 \mathrm{~L}$ of the deionized water was 8.3 hours and the landfill leathate was 7.0 hours. $\triangle \mathrm{HRT}$ was 2.1 hours in irrigation $39 \mathrm{~L}$ of the water and landfill leachate and 1.3 hours in the 9 L. To some extent, the landfill leathate increased the leakage of water and solute loss, and reduced the HRT of pollutants in soil. It was in accordance with Chen et al. [10]. Hydraulic load of the landfill leathate was $1.70 \times 10^{3} \mathrm{~m}^{3} /(\mathrm{ha} \cdot \mathrm{d})$ and it of the deionized water was $1.45 \times 10^{3} \mathrm{~m}^{3} /(\mathrm{ha} \cdot \mathrm{d})$, it was $16.9 \%$ higher than hydraulic load of the deionized water.

\section{Conclusion}

In 1 day after the treatment of furrow irrigation the landfill leathate, total nitrogen and total carbon remove 22.4 and $79.2 \%$ of efficiency rate from $9.8 \times 10^{2}$ and $4.8 \times 10^{3}$ $\mathrm{mg} \cdot \mathrm{L}^{-1}$ in the landfill leachate to $7.6 \times 10^{2}$ and $1.0 \times 10^{3}$ $\mathrm{mg} \cdot \mathrm{L}^{-1}$ in the soil water, respectively. Hydraulic load in the landfill leathate of $1.70 \times 10^{3} \mathrm{~m}^{3} /(\mathrm{ha} \cdot \mathrm{d})$ was $16.9 \%$ higher than it in the water of $1.45 \times 10^{3} \mathrm{~m}^{3} /(\mathrm{ha} \cdot \mathrm{d})$. As time goes by, the removal efficiency will be very higher than the 1 day. Furrow irrigating the landfill leathate in growing Reed onland may be a better method of treating the landfill leathate, which more and more will have being permeated by city solid waste.

\section{REFERENCES}

[1] K. D. Johnson and C. D. Martin, "Constructed Wet Lands for the Treatment of Landfill Leachate," Lewis Publishers, Chelsea, Vol. 1, 1998, pp. 63-69.

[2] D. M. Craig, D. J. Keith and A. M. Gerald, "Performance of a Constructed Wetland Landfill Leachate Treatment System at the Chunchula Landfill. Mobile County. Alabama," Water Science and Technology, Vol. 40, No. 3, 1999, pp. 67-74. doi:10.1016/S0273-1223(99)00453-9

[3] S. Rasmussen, "Locals Build Wetland to Ttreat Landfill Leachate," American City and County, Vol. 1, No. 10, 2000, p. 54.

[4] Y. Shi and X. N. Wan, "Constructed Wetland System in the Landfill Leachate Treatment," Soil and Water Conservation, Vol. 12, No. 1, 2005, pp. 56-58.

[5] US EPA, "Subsurface Flow Constructed Wetland for Waster Water Treatment a Technology Assessment," US EPA, Washington DC, 1993.

[6] C. Wu, "Municipal Landfill Leachate Treatment," Water and Wastewater, Vol. 22, No. 5, 1996, pp. 11-12.

[7] D. A. V. Eckhardt, "Constructed Wetland for the Treatment of Landfill Leachates," Lewis Publishers, Chelsea, Vol. 1, 1998, pp. 205-217.

[8] T. Maehlum, "Treatment of Landfill Leachate in On-Site Lagoons and Constructed Wetland," Water Science and Technology, Vol. 32, No. 3, 1995, pp. 129-135. doi:10.1016/0273-1223(95)00613-3

[9] G. W. Thomas and R. E. Philips, "Consequences of Water Movement in Macropores," Journal of Environmental Quality, Vol. 8, No. 2, 1979, pp. 149-152. doi: $10.2134 /$ jeq $1979.00472425000800020002 x$

[10] C. C. Chen, R. J. Roseberg and J. S. Selker, "Using Microsprinkler Irrigation to Reduce Leaching in a Shrink/ Swell Clay Soil," Agriculture Water Management, Vol. 54, No. 2, 2002, pp. 159-171. doi:10.1016/S0378-3774(01)00150-0

[11] L. W. Dekker and C. J. Ritsema, "Uneven Moisture Patterns in Water Repellent Soil," Geoderma, Vol. 70, No. 2-4, 1996, pp. 87-99. doi:10.1016/0016-7061(95)00075-5

[12] F. Hagedorn and M. Bundt, "The Age of Preferential Flow Paths," Geoderma, Vol. 108, No. 1-2, 2002, pp. 
119-132. doi:10.1016/S0016-7061(02)00129-5

[13] R. J. Glass, T. S. Steenhuis and J. Y. Parlange, "Wetting Front Instability as a Rapid and Far Reaching Hydrologic Process in the Vadose Zone," Journal of Contaminant Hydrology, Vol. 3, No. 2-4, 1998, pp. 207-226. doi:10.1016/0169-7722(88)90032-0

[14] B. Gjettermann, K. L. Nielsen, C. T. Petersen, et al., "Preferential Flow in Sandy Loam Soils as Affected by Irrigation Intensity," Soil Technology, Vol. 11, No. 2, 1997, pp. 139-152. doi:10.1016/S0933-3630(97)00001-9

[15] S. Reichenberger, W. Amelung, V. Laabs, et al., "Pesticide Displacement along Preferential Flow Pathways in a Brazilian Oxisol," Geoderma, Vol. 110, No. 1-2, 2002, pp. 63-86. doi:10.1016/S0016-7061(02)00182-9

[16] K. Lipsius and S. J. Mooney, "Using Image Analysis of Tracer Staining to Examine the Infiltration Patterns in a Water Repellent Contaminated Sandy Soil," Geoderma, Vol. 136, No. 3-4, 2006, pp. 865-875. doi:10.1016/j.geoderma.2006.06.005

[17] K. Täumer, H. Stoffregen and G. Wessolek, "Seasonal Dynamics of Preferential Flow in a Water Repellent Soil," Vadose Zone Journal, Vol. 5, No. 1, 2006, pp.
405-411. doi:10.2136/vzj2005.0031

[18] K. J. Winter and D. Goetz, "The Impact of Sewage Composition on the Soil Clogging Phenomena of Vertical Flow Constructed Wetland," Water Science and Technology, Vol. 45, No. 5, 2003, pp. 9-14.

[19] C. Platzer and K. Mauch, "Soil Clogging in Vertical Flow Reed Beds-Mechanisms, Parameters, Consequences and Solutions," Water Science and Technology, Vol. 35, No. 5, 1997, pp. 175-181. doi:10.1016/S0273-1223(97)00066-8

[20] J. Zhang, C. F. Shao, X. Huang, et al., "Land Treatment of Soil Clogging Process," China Water \& Wastewater, Vol. 19, No. 3, 2003, pp. 17-20.

[21] X. D. Cao, "Strengthen the Pond Wetland Complex Ecological Pond System to Remove Nitrogen and Phosphorus in the Law," Environmental Sciences, Vol. 13, No. 2, 2000, pp. 15-19.

[22] L.-H. Cui, X.-Z. Zhu and S.-M. Luo, "Infiltration Wetland Wastewater Treatment System Technology Research," Journal of Applied Ecology, Vol. 14, No. 4, 2003, pp. 623-626. 